\title{
Tensions and paradoxes in teaching: implications for teacher education
}

\author{
Miriam Ben-Peretz ${ }^{\mathrm{a}}$ and Maria Assunção Flores ${ }^{\mathrm{b}}$ \\ aFaculty of Education, University of Haifa, Haifa, Israel; ${ }^{\mathrm{b}}$ Institute of Education, University of Minho, Campus of \\ Gualtar, Braga, Portugal
}

\begin{abstract}
This paper focuses on the tensions and paradoxes in teaching. At present time, teacher education has the obligation to prepare teachers for diverse student populations, living in a highly varied context. This situation creates several competing expectations of the meaning of teacher education. For instance, preparing for professional autonomy in a world of externally imposed educational policy. The tension between achieving immediate results and success in external exams versus the need to prepare students in an era of migration and growing multiculturalism in school contexts is addressed. It is argued that a common knowledge base is a necessary response to growing multiculturalism while simultaneously leaving space in the curriculum for multicultural aspects of the student population. These double requirements have implications for teacher education which are discussed in the last section of the paper.
\end{abstract}

\section{ARTICLE HISTORY}

Received 19 August 2017

Accepted 19 January 2018

\section{KEYWORDS}

Teaching; teacher education; policy implementation; professional autonomy; multiculturalism

\section{Introduction}

Teachers' work has been affected by policy environments in many contexts in diverse ways. Several issues relating to the relationship between the societal environment and the content and process of teacher education has been chosen to be dealt with in this paper. These issues make teacher education a highly complex process raising many problems and having important implications for the process itself. Issues such as the rise of a performance culture through increased accountability and imposition of standards (Sachs (2016), the compliance of teachers with the demands of performance policies and the tyranny of audit (Lo 2012), the decline in teacher autonomy and an environment of distrust have been identified in many parts of the world (Sachs and Mockler 2012). Added to these are, more recently, issues of increased diversity of student populations and school contexts owing to migration and multiculturalism. All of these have implications for teachers' work and teacher education.

Teacher professionalism is shaped by external environments, and, in times of increased accountability and regulation, different discourses of professionalism proliferate, gaining legitimacy and impact on how professionalism is understood and enacted (Sachs 2016). Drawing attention to the 'multi-faceted and complex' nature of teachers' responses to 
imposed change, Osborn underlines that 'externally imposed requirements are mediated by the perceptions, understandings, motivation and capacity of both individual and groups of teachers in different contexts to produce particular practices and actions' (Osborn 2006, 252). Thus, in different times different responses are required (Sachs 2016).

Alexiadou and Essex claim that 'local practices of pedagogic differentiation are shaped by the demands of testing and league tables that seem to control what is possible in terms of classroom practice' $(2016,16)$. The authors advocate the need to go beyond simplistic notions of cultural otherness and to emphasise a 'more demanding practice of inclusion as academic process' which requires 'more investment in producing intellectually challenging content for diverse pupils, and in drawing on pedagogies that provide pupils with opportunities to develop social and academic identities as well as using "difference" as a resource' (Alexiadou and Essex 2016, 16). As classrooms have increasingly become diverse and complex culturally responsive pedagogies as a professional imperative for teachers are advocated (Santoro and Forghani-Arani 2015). Drawing on a study from Austria, the authors state that the intersection of student resistance and teacher authority raises problems of power issues, compliance and the construction of cultural difference. They discuss the enactment of mandated curriculum by teachers and show that there is only one way for them to do so. The authors conclude that

wider education discourses, such as curriculum policy, resourcing, mandated assessment practices and curricula, can privilege the knowledge of the dominant majority and work to reproduce unequal relations of power. In turn, these discourses can shape what is educationally possible as well as what teachers are able to envision. (Santoro and Forghani-Arani 2015, 66)

In this paper we look at current tensions and paradoxes in teaching. In the first part of the paper we look at the competing expectations of teachers' work related to the implementation of externally determined policy and the exercise of professional autonomy. We focus, as well, on the tension between achieving immediate results and success in external exams, versus the need to prepare students in an era of migration and growing multiculturalism in school contexts. It is argued that a common knowledge base is a necessary response to growing multiculturalism, while simultaneously leaving space in the curriculum for multicultural aspects of the student population. In the last part of the paper we discuss the implications for teacher education.

\section{The paradox of implementing external policy versus using professional autonomy}

There is a soul in some professions and teaching is one of them.... I guess you need a sense of vocation... All this change [policy initiatives] has affected the soul of teaching. It has affected the most beautiful side of teaching that makes a teacher smile to his/her pupils and having that energy that you don't know where it comes from... and this has been lost. I feel that teaching is all about this soul, this something else that in my view is hurt right now... (Teacher, 22 years of experience, Portugal)

Sometimes we find standards are not realistic, because the school is so driven by the national targets... A teacher then is judged on that ... you need a national target... but I think you need so much more into consideration. (Teacher, 20 years of experience, England)

These two quotes from two teachers who participated in research, carried out in Portugal and England (Flores 2011), illustrate some of the tensions and contradictions in teachers' 
work. Issues such as compliance with external, top-down initiatives, and outcome-driven orientation to teaching might contradict the exercise of professional judgments and the sense of vocation and commitment to students' learning. A look at international research literature over the last decades shows the ways in which teachers' work, and consequently their education, has been challenged and changed in different and sometimes conflicting ways (Livingston and Flores 2017).

In the next section we analyse the paradox of implementing external policy versus using professional autonomy in the light of international research literature. Several terms seem to govern the way teachers' work is presented in the literature. Among these terms, accountability, efficiency and effectiveness, as well as managerial professionalism play a central role. In general, trends in international research literature suggest that teachers' work has become increasingly demanding and complex over the last decades. Accountability, new forms of managerialism and a 'new vocabulary of performance' (Ball 2003, 7) have dominated the education agenda worldwide. This situation has implications for schools and teachers' work within the context of greater economic competitiveness in a globalised world.

Policy changes have been affecting teachers' sense of professionalism and the affective dimension of teaching as well as their moral purposes (Day 1997; Day, Flores, and Viana 2007; Flores, Day, and Viana 2007; Osborn 2006). For instance, a study of English and Portuguese teachers pointed to the increase in bureaucracy linked to an increase in workload and change of expectations of professionals. Issues related to discretionary judgement of teachers, as well as their moral/social purposes that were considered dimensions of their professionalism were under attack through national policies (Day, Flores, and Viana 2007). The same study also showed the contrasting influence of school leadership on the motivation, commitment and quality of work of teachers. Similarly, a study of the impact of national education policy, and policy change, on teachers' work and professional development in England, France and Denmark found that teachers expressed concerns in regard to what was perceived as the demand for a 'delivery of performance' (Osborn 2006). The author also found that many teachers claimed that the more affective concerns of teaching (the sense of vocation and investment of self) were being undermined by the pressure for performance. Teachers were expected to become 'expert technicians' in transmitting externally pre-defined knowledge and skills to their students. Another study carried out in Portugal showed that changes in educational policies that result in an excess of bureaucratic work have led to a growing sense of vulnerability. Most of the negative emotions were related to policy reform whereas positive ones were related to classroom interactions (Bahia et al. 2013).

This is particularly emphasised in contexts marked by intensive school reform and austerity measures related to issues of poverty and social justice. Student teachers' perceptions about poverty, as well as strategies they employ to deal with poverty in school, have major impact on children's well-being and their equal opportunities (Flores and Ferreira 2016). In the Irish context, Sugrue $(2006,183)$, discussing the impact of international agendas, highlights an increase in the performativity and accountability movement. He stresses its negative impact in terms of the 'marginalisation of other important values, as part of the educative process, with particular reference to the democratisation of schooling, citizenship and the health of society'.

The 'obsession with efficiency and effectiveness, with standards and tests, with general accountability procedures and even comparative rankings of schools in terms of quality' (Kelchtermans 2004, 224) has resulted in the marketisation and commodification of teaching. 
Day and Sachs $(2004,7)$ analyse the characteristics of managerial professionalism as well as democratic. They state that whereas managerial professionalism has system driven/ends, democratic professionalism has profession driven/ends. Managerial professionalism is externally regulated while democratic professionalism is professionally regulated. Managerial professionalism serves political ends, whereas democratic professionalism serves professional development. Managerial professionalism is competitive and market driven while democratic professionalism is collegial and profession driven. Managerial professionalism expects compliance with external control and democratic professionalism expects activism on behalf of professionals.

In many contexts, teachers found themselves under greater pressure to comply with external regulations and standards-based regimes aiming to improve the quality of teaching, learning and specially student outcomes. The pace and scope of the reforms is diverse in many countries but it is possible to identify trends related to a greater control over teachers' work (Osborn 2006), increased surveillance mechanisms (Day and Smethem 2009) and increased bureaucracy linked to an increase in workload (Flores 2012). Quality is viewed as effective and efficient achievement of standards in terms of student outcomes and teacher performance (Kelchtermans 2009).

Despite externally imposed changes on schools and teachers' work, it seems that teachers respond differently to school reform and policy initiatives. Some teachers comply with them, even if sometimes disagreeing; others translate them into practice in different ways and others seem to resist and maintain their commitment and effectiveness in times of instability and pressure due to their resilience and sense of identity (Day and Smethem 2009; Flores 2011, 2012; Flores, Ferreira, and Parente 2014; Osborn 2006). In the next section, we present results from a national survey carried out in Portugal that analyses the ways in which teachers view their work in policy context.

\section{The teaching profession in the eyes of teachers}

Teaching is embedded in political, social, economic and cultural contexts. Moreover, teachers ascribe different meanings to their daily work in schools and experience their professional contexts in different ways. Beyond these different aspects, the values and aspirations are key to understanding the nature of teacher professionalism and to document 'the everyday work of teaching' (Hargreaves and Goodson 1996, 23).

In a nationwide survey carried out in Portugal, in which 2702 teachers participated, it was concluded that recent policy initiatives associated with a context of austerity and economic crisis, had a deep influence on teachers. This situation led to greater control of teachers' work, to an increase of their workload and bureaucracy and to a deterioration of their working conditions including their social economic status. This study also indicated that teachers have been subject to greater public scrutiny and that the image of teaching and teachers in the media has contributed to the deterioration of the teaching profession as well as to a decrease in teachers' motivation (Flores, Ferreira, and Parente 2014).

When teachers were asked about the most important dimensions of their work, they cited several highly relevant dimensions as well as some less important ones. Among the most important dimensions are: collaborating with colleagues (63.4\%); supporting students (58.7\%); reflecting on one's own work (51.1\%); planning teaching $(49.1 \%)$ and continuous professional learning (45.1\%). The less relevant dimensions of their work were: performing 
administrative tasks (7.5\%); involvement within the local community (14.5\%); developing teamwork (18.7\%), using ICT (19.7\%) and participating in decision-making processes (19.7\%). It is interesting to note the ambivalence in regard to team work, on one hand, and teacher collaboration, on the other hand. These apparent inner contradictions might be explained as related to the source of teacher collaboration and team work. On one hand, these activities might be organised through top down compulsory meetings at schools. On the other hand, collaboration might be initiated and fostered by the teachers themselves. In other words, teachers seem to value the individual and collective understandings of their professionalism in contrast to its managerial dimension.

Thus, it seems that a crucial aspect in teachers' work relates to the source of their activities. Teachers prefer to be decision makers in how to divide their work into different components such as planning teaching, collaborating with colleagues and supporting students. Top-down initiatives are not comparable in teacher's eyes with the same kind of activities organised by themselves. There seems to be a difference between compulsory and authentic collaboration of teachers, as claimed by Hargreaves (1998).

These findings parallel those in other countries which relate to current tensions and contradictions that mark teachers' work. Looking at the opportunities and threats in teaching, amongst other features, Hargreaves and Fullan $(2012,43)$ noted that there was 'more interactive professionalism among teachers' but they also warned that it 'can turn into hyperactive professionalism as teachers are thrown into hurried meetings to devise quick-fix solutions that will lead to instantaneous gains in student achievement results' (Hargreaves and Fullan 2012, 43).

Boote $(2006,473,474)$ warns of the 'common mistake' to 'focus on either the limitations or the enhancement of professional discretion within an institutional culture without examining their interplay and tradeoffs, leading people to see the dual imperatives for autonomy and accountability as paradox'. He argues for a'robust conception of professional discretion that articulates the complex and dynamic interplay among individual and social, normative and descriptive aspects of teaching'. In the next section we explore the possibilities and opportunities for teacher agency and professionalism in contexts marked by accountability and performativity agendas.

\section{Teacher agency and professionalism}

Teacher professional agency relates to the ability of teachers to control their work within structural constraints (Quinn and Carl 2015). Teachers' control of their work is a key capability for facilitating student learning, as well as for continuing individual and collective teacher professional development (Toom, Pyhältö, and Rust 2015).

According to Buchanan's study $(2015,715)$ many teachers feel a greater sense of constraint; while some accept the limited scope of teaching promoted by the proliferation of high-stakes standardised testing, others tend to resist or leave the profession. Robinson $(2012,231)$ found that although teacher routines and practices were reshaped as a result of external policies, professional agency might be sustained because of teachers' ability to adapt creatively to policy constraints. She concludes that, despite 'the strategies of performance, accountability and control mechanisms in policy text, the existence of strong collegial relationships enabled the teachers to construct their professional agency by adaptation and adoption of policy requirements to fit some practices and reshape others'. 
Drawing upon empirical research, Van der Heijden et al. (2015) identify a set of characteristics attributed to teachers as change agents including issues related to (i) lifelong learning (being eager to learn and reflect), (ii) mastery teaching (giving guidance, being accessible, positive, committed, trustful, and self-assured), (iii) entrepreneurship (being innovative and feeling responsible), and (iv) collaboration (being collegial).

Priestley et al. (2012) argue for an ecological view of agency as it varies from context to context as a result of given environmental conditions of possibility and constraint. Important factors in teachers' agency relate to the beliefs, values and attributes that teachers mobilise in particular situations. Teachers' individual and collective agency involves a dynamic relation between motivation, intentions and power relations (Priestley et al. 2012). Thus, teachers' agency depends not only on the beliefs that individual teachers bring to their practice, but requires as well collective development and consideration (Biesta, Priestley, and Robinson 2015). According to Biesta, Priestley, and Robinson (2017) agency is 'both a temporal and a relational phenomenon; it is something that occurs over time and is about the relations between actors and the environments in and through which they act' (Biesta, Priestley, and Robinson 2017, 40). Issues such as the role of teachers in curriculum development are determined by policy environment, school leadership and cultures. The nature and dynamic of teachers' interactions, their beliefs and professional values, are to be considered to fully understand the ways in which they respond to the challenging and sometimes contradictory nature of their work. All these variables, and the interplay between them, are key to understanding teacher professionalism in context and the use teachers make of their professional judgement. Teachers might be situated within constrained professionalism as their autonomy in classroom contexts might be influenced by standardisation of curriculum and national exams (Willis and Haymore Sandholtz 2009). Teacher decisions might be circumscribed by contextual pressures and time demands that influence their professional judgment and expertise. Conversely, teachers might make use of their professional space even in contexts marked by growing standardisation (Oolbekkink-Marchand et al. 2017).

\section{The tension between obtaining immediate results and preparing students for multiculturalism in schools}

Over the last decades, schools and teachers have been confronted with new challenges, including multiculturalism, changes in social agencies regarding family welfare, competing educational agenda, migration and implications for teaching and learning in the digital era. Teachers' work has become more fragmented and complex and more demanding in terms of creating learning situations for an increasing number of diverse student populations (Day 1999; Day and Sachs 2004; Estrela 2001; Hargreaves 2001; Klette 2002). At present teachers have to work in multicultural settings often within the context of more and more outcome-oriented education systems. Thus, they found themselves in the middle of a set of tensions as identified in the context of Nordic countries: (i) 'the tension between a wider cultivating and moral mission of teaching on the one hand, and a narrow instrumental mission of teaching' on the other hand; (ii) 'increasing autonomy versus increased control of teachers', in which the rhetoric of teachers being autonomous professionals co-exists with 'growing systems of control mechanisms and of external constraints and demands' (Klette $2002,267)$. Similarly, it is possible to identify the increasing pressure on teachers in terms of student attainment while at the same accounting for their 'well-being' and citizenship (Day 
and Smethem 2009). Another pressure is for teachers to collaborate (an 'imposed' collaboration) accompanied by increasing forms of managerialism and accountability in their work, along with a greater focus on student and school outcomes (Flores 2012).

Research suggests that teachers experience intense emotional ambivalence in their efforts to cope with growing diversity and multiculturalism in schools (Zembylas 2010). On one hand, issues of social justice and poverty, and the cultural and social aspects of teaching, might suffer lack of attention (Flores and Ferreira 2016). On the other hand, creating an ethic of discomfort offers opportunities to challenge structures of power, privilege, racism, and oppression (Zembylas 2010).

Multiculturalism has been a hot topic, not necessarily consensual, in discussions about education in many contexts (e.g. Boese and Phillips 2011; Coronel and Gómez-Hurtado 2015; Forrest, Lean, and Dunn 2016; Pruitt 2016; Santoro 2009). For instance, culturally responsive teaching is discussed arguing for the need to restructure teacher attitudes and beliefs about cultural, ethnic, and racial diversity (Gay 2013). It is important to accept cultural diversity in teacher education and classroom instruction, establishing pedagogical connections between culturally responsive teaching and subjects and skills routinely taught in schools.

Research carried out in Spain found that within the context of increasing immigration, teachers perceive cultural diversity as a particular problem whose management is marginalised and excluded from school activities and teaching practices (Coronel and GómezHurtado 2015). They also found that teachers point to a perspective of adaptation, a problem to be solved by the students themselves with the support of school counsellors and other educational specialists. Global and multicultural society generates the need for intercultural learning with different school subjects contributing facts, theories, concepts and methods that can be powerful for developing intercultural competence (Nordgren 2017). Nordgren (2017) suggests that asking the question, 'what is powerful knowledge in a specific subject for understanding and relating to a multicultural society in a globalised world?' has the potential to identify how each subject might contribute to intercultural learning.

\section{Multiculturalism in teacher education}

The need for issues of diversity and multicultural perspectives to be included in initial teacher education has been advocated by several scholars (Acquah and Commins 2013; Coronel and Gómez-Hurtado 2015). A study carried out in Australia suggests that pre-service teachers hold simplistic understandings of their students' cultures and limited insights of how their own identities are constituted through, and by, ethnicity (Santoro 2009). In research carried out in Portugal, it is argued that there is a need to foster social and cultural dimensions in teacher education (Flores and Ferreira 2016). Also, a study in the USA points to the need for more systematic and integrated approaches to teacher learning in new immigrant locations. It is necessary to move beyond the short-term need for instructional strategies to develop more holistic and collaborative approaches to integrating English language learners into schools and classrooms (Lowenhaupt and Reeves 2017). The same authors argue that opportunities for teacher learning are crucial for developing the school ability to serve the academic, linguistic and socio-cultural needs of immigrant students.

Thus, it is possible to identify the emergence of tensions between achieving success in exams versus the need to prepare students for learning in an era of migration and growing multiculturalism. What is at stake is the responsiveness to the increasingly socially and 
culturally diverse contexts of teaching within the perspective of democratisation of schooling. Teachers are to be seen as workers of knowledge who play a key role in promoting the social and cultural dimension of children and their families (Flores and Ferreira 2016). Teachers are viewed as curriculum makers and agents of change who are able to adapt the curriculum to the multicultural contexts in which they work.

A common knowledge base is a necessary response to growing multiculturalism while simultaneously leaving space in the curriculum for multicultural aspects of the students' population. These double requirements have implications for teacher education. A common knowledge base of teaching refers to those components of the teaching profession which are shared by teachers in every teaching situation. These components are: the content to be taught, the act of the teacher and the learning activities of the students. The cognitive domain, mentioned by Bloom in his analysis of teaching and learning (Bloom et al. 1956), is one mode of relating to this common knowledge base. Bloom describes several levels of cognitive learning such as remembering, comprehending, applying, analysing, synthesising and evaluating. All these levels have to be components of teachers' professional knowledge. Teaching requires the kind of knowledge concerning the subjects to be learned, as well as knowledge about the nature of students and the conditions of the learning situation (Shulman 1987). Some parts of this kind of knowledge might be acquired before actual work in teaching. Still, some parts of knowledge are acquired through concrete teaching practice. Such learning transforms a general view of learners into awareness of the nature of specific students and classroom situations. The general term 'student' becomes a picture of real life images of learners. This transformation allows teachers to inter-act with students in their own classrooms, but might limit their understanding of different situations. A teacher, who has experience with teaching a certain topic in math in his/her own classroom, might not be aware of other options of teaching the same content. Concrete teaching experiences shape the professional knowledge of teachers. In order to widen their professional horizon, teachers require ongoing in-service experiences as well as opportunities for collaborative learning in the workplace.

\section{Implications for the future of teacher education}

Teacher education needs to respond to increasing demands of the multicultural contexts in which teachers have to work. The need to develop inclusive pedagogies and social competence in teacher education has been advocated by many scholars (Tynjälä et al. 2016; Väyrynen et al. 2016). It has been recommended to promote initial teacher education diversity and intercultural competence (Keane and Heinz 2016). Teaching about culture in teacher education is recognised as a challenging task (Ogay and Edelmann 2016). The authors identify intercultural metaphors of culture and argue for the dynamic and complex understanding of culture and cultural diversity in education.

The need for pedagogies of praxis that move beyond (and sometimes against) the official policy definitions of inclusion is highlighted in England by Alexiadou and Essex (2016). They draw on a more critical approach to the development of future professionals and they recognise that teacher education can act as an important agency in achieving inclusion within classrooms. In demanding and contradictory school contexts marked by performative cultures and by the need to meet the increasingly diverse expectations and backgrounds of student populations, teachers find themselves in the middle of tensions and paradoxes that 
are not easy to deal with. Policy environments that are more and more outcome-oriented and school contexts that call for different responses to students' needs require teachers to master knowledge and competences to handle diversity, inclusiveness and multiculturalism but also with accountability and competitive logics.

As Sachs and Mockler (2012) argue, the 'cultures of performativity' might be seen both as a threat and as an opportunity. They argue for a 'perspective of development' that conciliates the interests of various stakeholders, community, teachers, parents, students (Sachs and Mockler 2012). This perspective tries to balance externally imposed accountability with the development needs of teachers. Ben-Peretz (2012) discusses the effects of the external surveillance mechanisms and the logics of regulation and measurement that have extended teachers' dilemmas as professional educators and interpreters of educational policies. She argues for the need to find a balance between accountability and professional autonomy in order to adapt accountability policies to the contexts of teachers. Similarly, it is advocated that the teaching profession needs to revitalise its professionalism in face of the adversities through a more activist position, and the promotion of essential values (Lo 2012).

There is a need to foster in teacher education both the technical and cognitive dimensions of teaching, as well as its social and cultural dimensions. It is important to include a set of competencies for 'professional and ethical' teachers in light of the moral dimension of their work dealing with a rising number of immigrant students and children with learning difficulties (Tirri 2014). Teachers are seen as ethical professionals whose education requires more than teaching and management skills (Zeichner 2014).

In our view a common knowledge base of teaching is a necessary response to growing multiculturalism simultaneously leaving space in the curriculum for multicultural aspects of the student population. Such an approach might structure teacher education programmes that have a common core of general topics, such as teaching and learning modes, that apply to all students. This core might be accompanied by courses focusing on diverse ethnic-cultural groups, with their specific histories and traditional modes of teaching and learning. Such a global view of teacher education programmes might serve the creation of some unity in processes of teaching and learning, on one hand, while expanding the world of potential diversity and learning about others, on the other hand. As human beings we share some unifying characteristics, while celebrating as well our cultural diversity. A film called 'babies' (2010) showed how different cultures treat their children in the first year of life. The differences are enormous, but in the end all children learn to walk and talk.

\section{Disclosure statement}

No potential conflict of interest was reported by the authors.

\section{Notes on contributors}

Miriam Ben-Peretz is a Professor Emeritus at the Department of Education at the University of Haifa, Israel. She has been Chair of the Department of Teacher Education and Dean of the School of Education at the University of Haifa, as well as president of Tel-Hai College. Her research interests are curriculum, teacher education and professional development, policy-making and Jewish education. In 1997, she was awarded the Lifetime Achievement Award by the American Educational Research Association (AERA) for her contribution to curriculum studies. She is the 2006 Laureate of the Israel Prize for research in education. Since 2009 she is a member of the National Academy of Education in the US (NAEd). 
In 2012, she was the recipient of the American Educational Research Association, Division K Legacy award and is an Honorary Fellow of the Open University of Israel. In 2015, she has received the Israeli Prime Minister award, the EMET prize for educational research.

Maria Assunção Flores is an associate professor with Qualification at the University of Minho, Portugal. She received her PhD in Education at the University of Nottingham, UK, in 2002. She was a visiting scholar at the University of Cambridge in 2008/2009 and at the University of Glasgow, UK, in 2016/2017. She has published extensively in international and national journals, books and book chapters. Her research interests include teacher education and professional development, teacher evaluation, curriculum, assessment, teacher identity and higher education. She is currently the Chair of the International Study Association on Teachers and Teaching (ISATT) and President of the Board of Estreiadiálogos (The International Collaborative Action Research Network for the Portuguese speaking countries).

\section{References}

Acquah, E. O., and N. L. Commins. 2013. "Pre-Service Teachers' Beliefs and Knowledge about Multiculturalism." European Journal of Teacher Education 36 (4): 445-463.

Alexiadou, N., and J. Essex. 2016. "Teacher Education for Inclusive Practice - Responding to Policy." European Journal of Teacher Education 39 (1): 5-19.

Bahia, S., I. Freire, A. Amaral, and M. T. Estrela. 2013. “Then Emotional Dimension of Teaching in a Group of Portuguese Teachers." Teachers and Teaching Theory and Practice 19 (3): 275-292.

Ball, S. 2003. "The Teacher's Soul and the Terrors of Performativity." Journal of Education Policy 18 (2): 215-228.

"Babies." 2010. Directed by Thomas Balmès.

Ben-Peretz, M. 2012. "Accountability Vs. Teacher Autonomy. an Issue of Balance." In The Routledge International Handbook of Teacher and School Development, edited by C. Day, 57-66. London: Routledge

Biesta, G., M. Priestley, and S. Robinson. 2015. "The Role of Beliefs in Teacher Agency." Teachers and Teaching Theory and Practice 21 (6): 624-640.

Biesta, G., M. Priestley, and S. Robinson. 2017. "Talking about Education: Exploring the Significance of Teachers' Talk for Teacher Agency." Journal of Curriculum Studies 49 (1): 38-54.

Bloom, B. S., M. D. Engelhart, E. J. Furst, W. H. Hill, and D. R. Krathwohl. (1956). "Taxonomy of Educational Objectives: The Classification of Educational Goals." In Handbook I: Cognitive Domain. New York: David McKay Company. Inc.(7th Edition 1972).

Boese, M., and M. Phillips. 2011. "Multiculturalism and Social Inclusion in Australia." Journal of Intercultural Studies 32 (2): 189-197.

Boote, D. N. 2006. “Teachers' Professional Discretion and the Curricula." Teachers and Teaching: Theory and Practice 12 (4): 461-478.

Buchanan, R. 2015. "Teacher Identity and Agency in an Era of Accountability." Teachers and Teaching Theory and Practice 21 (6): 700-719.

Coronel, J. M., and I. Gómez-Hurtado. 2015. “Nothing to Do with Me! Teachers' Perceptions on Cultural Diversity in Spanish Secondary Schools." Teachers and Teaching Theory and Practice 21 (4): 400-420.

Day, C. 1997. "Teachers in the Twenty-First Century: Time to Renew the Vision." In Beyond Educational Reform. Bringing Teachers Back in, edited by A. Hargreaves and R. Evans, 44-61. Buckingham: Open University Press.

Day, C. 1999. Developing Teachers. the Challenges of Lifelong Learning. London: Falmer Press.

Day, C., M. A. Flores, and I. Viana. 2007. “Effects of National Policies on Teachers'Sense of Professionalism: Findings from an Empirical Study in Portugal and in England." European Journal of Teacher Education 30 (3): 249-266.

Day, C., and J. Sachs. 2004. "Professionalism, Performativity and Empowerment: Discourses in the Politics, Policies and Purposes of Continuing Professional Development." In International Handbook on the Continuing Professional Development of Teachers, edited by C. Day and J. Sachs, 3-32. Maindenhead: Open University. 
Day, C., and L. Smethem. 2009. "The Effects of Reform: Have Teachers Really Lost Their Sense of Professionalism?" Journal of Educational Change 10: 141-157.

Estrela, M. T. 2001. "Questões De Profissionalidade E Profissionalismo Docente [Issues of teacher professionality and professionalism]." In Ser Professor No Limiar Do Século XXI, edited by M. Teixeira, 113-142. Porto: ISET.

Flores, M. A. 2011. “Tendências E Tensões No Trabalho Docente: Reflexões a Partir Da Voz Dos Professores [Trends and tensions in teachers' work: A study of teachers' voices]." Perspectiva. Revista Do Centro De Ciências Da Educação 29 (1): 161-191. Florianópolis: NUP/CED.

Flores, M. A. 2012. "Teachers' Work and Lives: A European Perspective." In The Routledge International Handbook of Teacher and School Development, edited by C. Day, 94-107, London: Routledge.

Flores, M. A., C. Day, and I. C. Viana. 2007. "Profissionalismo Docente Em Transição. as Identidades Dos Professores Em Tempos De Mudança. Um Estudo Com Professores Ingleses E Portugueses." In Profissionalismo Docente Em Transição. as Identidades Dos Professores Em Tempos De Mudança, edited by M. A. Flores and I. C. Viana Braga, 7-35. Braga: CIEd.

Flores, M. A., and F. I. Ferreira. 2016. "Education and Child Poverty in times of Austerity in Portugal: Implications for Teachers and Teacher Education." Journal of Education for Teaching 42 (4): 404-416.

Flores, M. A., F. I. Ferreira, and C. Parente. 2014. "Conclusões E Recomendações." In Profissionalismo E Liderança Dos Professores, edited by M. A. Flores, 217-236. Santo Tirso: De Facto Editores.

Forrest, J., G. Lean, and K. Dunn. 2016. "Challenging Racism through Schools: Teacher Attitudes to Cultural Diversity and Multicultural Education in Sydney." Australia, Race Ethnicity and Education 19 (3): 618-638.

Gay, G. 2013. "Teaching to and through Cultural Diversity." Curriculum Inquiry 43 (1): 28-70.

Hargreaves, A. 1998. Os Professores Em Tempos De Mudança: O Trabalho E a Cultura Dos Professores Na Idade Pós-Moderna. Alfragide: McGraw-Hill.

Hargreaves, A. 2001. “Teaching as a Paradoxical Profession: Implications for Professional Development." In Continuing Teacher Education and School Development (Symposium Proceedings), edited by P. Xochellis and Z. Papanaoum, 26-38. Thessaloniki: Department of Education, School of Philosohy AUTH.

Hargreaves, A., and M. Fullan. 2012. Professional Capital: Transforming Teaching in Every School. New York: Teachers College Press.

Hargreaves, A., and I. Goodson. 1996. "Teachers' Professional Lives: Aspirations and Actualities." In Teachers' Professional Lives, edited by I. Goodson and A. Hargreaves, 1-27. London: Falmer Press.

Keane, E., and M. Heinz. 2016. "Excavating an Injustice?: Nationality/les, Ethnicity/les and Experiences with Diversity of Initial Teacher Education Applicants and Entrants in Ireland in 2014." European Journal of Teacher Education 39 (4): 507-527.

Kelchtermans, G. 2004. "CPD for Professional Renewal: Moving beyond Knowledge for Practice." In International Handbook on the Continuing Professional Development of Teachers, edited by C. Day and J. Sachs, 217-237. Maidenhead: Open University Press.

Kelchtermans, G. 2009. “O Comprometimento Profissional Para Além Do Contrato: Auto-Comprensão, Vulnerabilidade E Reflexão Dos Professores." In Aprendizagem E Desenvolvimento Profissional De Professores: Contextos E Perspectivas, edited by M. A. Flores and A. M. Veiga Simão, 61-98. Mangualde: Edições Pedago.

Klette, K. 2002. "Reform Policy and Teacher Professionalism in Four Nordic Countries." Journal of Educational Change 3 (3/4): 265-282.

Livingston, K., and M. A. Flores. 2017. Editorial. "Trends in Teacher Education: A Review of Papers Published in the European Journal of Teacher Education over 40 Years." European Journal of Teacher Education 40 (5): 551-560.

Lo, L. N. K. 2012. "Introduction." In The Routledge International Handbook of Teacher and School Development, edited by C. Day, 13-18. London: Routledge

Lowenhaupt, R., and T. D. Reeves. 2017. “Changing Demographics, Changing Practices:Teacher Learning in New Immigrant Destinations." Journal of Professional Capital and Community 2 (1): 50-71.

Nordgren, K. 2017. "Powerful Knowledge, Intercultural Learning and History Education." Journal of Curriculum Studies: 7-20. doi:10.1080/00220272.2017.1320430. 
Ogay, T., and D. Edelmann. 2016. "'Taking Culture Seriously': Implications for Intercultural Education and Training." European Journal of Teacher Education 39 (3): 388-400.

Oolbekkink-Marchand, H. W., L. L. Hadar, K. Smith, and I. Helleve. 2017.“"Teachers' Perceived Professional Space and Their Agency." Teaching and Teacher Education 62: 37-46.

Osborn, M. 2006. “Changing the Context of Teachers'Work and Professional Development: A European Perspective." International Journal of Educational Research 45: 242-253.

Priestley, M., R. Edwards, A. Priestley, and K. Miller. 2012." Teacher Agency in Curriculum Making: Agents of Change and Spaces for Manoeuvre." Curriculum Inquiry 42 (2): 191-214.

Pruitt, L. J. 2016. "Multiculturalism at Play: Young People and Citizenship in Australia." Journal of Youth Studies 19 (2): 269-285.

Quinn, R., and N. M. Carl. 2015. "Teacher Activist Organizations and the Development of Professional Agency." Teachers and Teaching Theory and Practice 21 (6): 745-758.

Robinson, S. 2012. “Constructing Teacher Agency in Response to the Constraints of Education Policy: Adoption and Adaptation." The Curriculum Journal 23 (2): 231-245.

Sachs, J. 2016. "Teacher Professionalism: Why Are We Still Talking about It?" Teachers and Teaching Theory and Practice 22 (4): 413-425.

Sachs, J., and N. Mockler. 2012. "Performance Cultures of Teaching. Threat or Opportunity?" In The Routledge International Handbook of Teacher and School Development, edited by C. Day, 33-43. London: Routledge

Santoro, N. 2009. "Teaching in Culturally Diverse Contexts: What Knowledge about 'Self' and 'Others' Do Teachers Need?" Journal of Education for Teaching 35 (1): 33-45.

Santoro, N., and N. Forghani-Arani. 2015. "Interrogating Practice in Culturally Diverse Classrooms: What Can an Analysis of Student Resistance and Teacher Response Reveal?" European Journal of Teacher Education 38 (1): 58-70.

Shulman, L. S. 1987. “Knowledge and Teaching: Foundations of the New Reform." Harvard Educational Review 57 (1): 1-23.

Sugrue, C. 2006. "A Critical Appraisal of the Impact of International Agencies on Educational Reforms and Teachers' Lives and Work: The Case of Ireland?" European Educational Research Journal 5 (3/4): 181-195.

Tirri, K. 2014. “The Last 40 Years in Finnish Teacher Education.” Journal of Education for Teaching 40 (5): 600-609.

Toom, A., K. Pyhältö, and F. Rust. 2015. “Teachers' Professional Agency in Contradictory times.” Teachers and Teaching Theory and Practice 21 (6): 615-623.

Tynjälä, P., A. Virtanen, U. Klemola, E. Kostiainen, and H. Rasku- Puttonen. 2016. “Developing Social Competence and Other Generic Skills in Teacher Education:Applying the Model of Integrative Pedagogy." European Journal of Teacher Education 39 (3): 368-387.

Van der Heijden, H. R. M. A., J. J. M. Geldens, D. Beijaard, and H. L. Popeijus. 2015. "Characteristics of Teachers as Change Agents." Teachers and Teaching Theory and Practice 21 (6): 681-699.

Väyrynen, S., E. Kesälahti, T. Pynninen, J. Siivola, N. Flotskaya, S. Bulanova, O. Volskaya, Z. Usova, T. Kuzmicheva, and Y. Afonkina. 2016. "Finnish and Russian Teachers Supporting the Development of Social Skills." European Journal of Teacher Education 39 (4): 437-451.

Willis, J. S., and J. Haymore Sandholtz. 2009. “Constrained Professionalism: Dilemmas of Teaching in the Face of Test Based Accountability." Teachers College Record 111 (4): 1065-1114.

Zeichner, K. 2014. "The Struggle for the Soul of Teaching and Teacher Education in the USA." Journal of Education for Teaching 40 (5): 551-568.

Zembylas, M. 2010. “Teachers' Emotional Experiences of Growing Diversity and Multiculturalism in Schools and the Prospects of an Ethic of Discomfort." Teachers and Teaching Theory and Practice 16 (6): 703-716. 